\title{
Problems and prospects of Ukrainian Advocacy development: Euro-integration discourse
}

\author{
Rostyslav Sopilnyk ${ }^{1}$, Yurii Semchuk ${ }^{2}$
}

Received: 2021-03-05

Accepted: 2021-04-10

DOI: http://doi.org/10.46489/gpj.2021-1-1-4

\begin{abstract}
European integration is now one of the central issues of politics, economics, law, and sociology. Changes in the legal consciousness of citizens, the turn of the political and legal situation that occurred as a result of the Revolution of Dignity led to the actualisation of fundamentally new requirements for the functioning of legal institutions. In this article, we explored the legal profession of Ukraine in the framework of European integration transformations. We have explored the theoretical basis of the processes of globalisation and European integration, which have a significant impact on legal reform in Ukraine. In particular, we have established the main models of European integration and the features of the European integration paradigm. We compared the current development goals of the Bar of Ukraine and the requirements that arise in connection with the Euro-integration discourse. This article can help elaborate a Ukrainian Advocacy development strategy in the Eurointegration discourse.
\end{abstract}

Keywords: advocacy of Ukraine, globalisation, European integration, models of European integration, legal reform in Ukraine.

\footnotetext{
${ }^{1}$ Rostyslav Sopilnyk, D.Sc. (Law), Professor, Professor of the Department of Judiciary, Prosecution and Advocacy, Lviv University of Business and Law, 99 Kulparkivska Str., Lviv, 79021, Ukraine, rostyslav.sopilnyk@ukr.net, ORCID: https://orcid.org/0000-0001-9942-6682

2 Yurii Semchuk, PhD, Assosiated Professor of the Department of Judiciary, Prosecution and Advocacy, Lviv University of Business and Law, 99 Kulparkivska Str., Lviv, 79021, Ukraine, ORCID: https://orcid.org/00000002-2829-0834
} 


\section{ВСТУП}

Питання розвитку інституту адвокатури, його реформування та приведення у відповідність до європейських стандартів неодноразово піднімалось у сучасних наукових дослідженнях та при обговоренні змін до профільного Закону. Питання глобалізації, євроінтеграції та розвитку адвокатури досліджували Абашидзе А. Х., Арутюнян Г.Г., Бліщенко В. И., Вільчик Т. Б., Дудаш Т. І., Кашкін С. Ю., Коваленко Є. О., Прилуцький С. В., Сталовєров В.М., Тихомиров Ю. А., Шкребець Є. У даній статті пропонується поглиблене дослідження впливу євроінтеграційної парадигми правової реформи на розвиток адвокатури.

Метою статті $\epsilon$ обгрунтування євроінтеграційного вектору розвитку адвокатури України.

\section{РЕЗУЛЬТАТИ}

Європейська інтеграція нині $\epsilon$ одним із центральних питань політики, економіки, права, соціології. Зміни у правосвідомості громадян, перелом політико-правової ситуації, що стався унаслідок Революції Гідності обумовили актуалізацію принципово нових вимог до функціонування правових інститутів.

С. Ю. Кашкін (2012) наголошує 3 приводу взаємовпливів процесів глобалізації і інтеграції у правовому вимірі, що процеси інтеграції та глобалізації мають велике значення для гармонізації економічних, політичних, культурних, ідеологічних та інших факторів, під впливом яких функціонує право. Вони впливають і на міжнародне, i на конституційне право, а також на будь-яку галузь законодавства, створюючи базу загальних тенденцій розвитку сучасного права.

Розглядаючи глобалізацію на європейському рівні Г.Г. Арутюнян (2004) наголошує на тенденціях, що впливають на систематизацію принципів правової демократичної держави, домінацію демократичних конституційних цінностей; визначають обмеження влади, розсіювання політичних, економічних i адміністративних сил за одночасного зміцнення гарантій та розширення можливостей інститутів самоуправління.

Ю. А. Тихомиров (2004) наголошує на наступній тенденції. Остання третина XX i початок XXI століть характеризуються тенденцією посиленого взаємопроникнення різних правових норм. 3 одного боку, у міжнародному праві i особливо у правових системах міжнародних об'єднань зростає питома вага норм, що «прийшли» 3 національного права. Держави гостріше відчувають потребу в забезпеченні захисті національних інститутів за допомогою механізму міжнародно-правового регулювання. Норми про права людини і громадянина, про парламентські, муніципальні і судові інститути «переміщуються» та набувають образ і статус міжнародноправових принципів, інститутів і норм. 3 іншого боку, у системах національного права все більшою стає питома вага схвалених міжнародних норм такого виду. У новому концентрованому вигляді вони як би повертаються в національне право, зливаючись 3 ним та збагачуючи його. Такі міжнародні норми стають правотвірним і оціночним фактором для відповідних національних інститутів і норм.

Поняття

євроінтеграційної парадигми $\epsilon \quad$ концептуально детермінованим розумінням змісту процесів євроінтеграції, їх теоретичного та методологічного підгрунтя.

Європейська інтеграція осмислюється крізь призму різних моделей, що базуються на векторах розвитку поглиблення та розширення. До основних моделей належать (Dudash T. I., 2013):

a) одночасний розвиток багатьох організацій - забезпечення розвитку 
через системне удосконалення та співпрацю європейських організацій, якот Рада Європи, ОБСЄ, ЦЄІ та ін.;

б) модель часткового членства участь асоційованих держав у певних заходах, що переважно здійснюються міжнародними організаціями на засадах інтеграції у довгостроковій перспективі;

в) модель «гнучкої Європи» базується на принципах вільного вибору міри участі держави $\mathrm{y}$ інтеграційних проектах, що обирається у відповідності до національних інтересів; модель відображає ідею неоднакового методу інтеграції, який дає змогу країнам-членам обирати стратегії;

г) модель «Європа концентричних кіл - передбачає наявність трьох різною мірою інтегрованих кіл держав: а) асоційовані з ЄС (зовнішнє коло); б) усі країни ЄС (середнє коло); в) держав, готові до тіснішої інтеграції в окремих областях (ядро).

Слід відзначити, що євроінтеграція України $є$ одним з конкретних проявів процесу глобалізації, котрий охопив світ у двадцятому столітті та у різних формах продовжує визначати національну політику багатьох країн. В. I. Бліщенко (2004) підкреслює, що феномен глобалізації $\epsilon$ одним із найбільш вагомих факторів, що визначає основи розвитку цивілізації та усіх країн світу на зламі XX та XXI століть. Глобалізація, за переконанням науковця, $\epsilon$ найвищим рівнем інтернаціоналізації суспільного життя, що характеризується пріоритетом міжнародних, глобальних чинників економічного, політичного, етнічного, релігійного, військового та екологічного розвитку над відповідними чинниками національного та регіонального рівнів.

А. Х. Абашидзе (2004) наголошує, що людство вступило в стадію глобалізації, яка набула незворотного характеру, утім до кінця неосмисленими залишаються питання сумісності глобалізації, економічних і соціальних реформ та прав людини. Г.Г. Арутюнян (2004) виокремлює низку значимих тенденцій, котрі характеризують сучасні процеси глобалізації:

а) досягнення демократичним розвитком у міжнародному плані певних якісних меж, що вимагає нового рівня та якості системної гармонійності і стійкості для подолання конфлікту між пріоритетами сьогодення та майбутнього;

б) наявність суперечностей між встановленням принципів правової демократії у внутрішньодержавних відносинах та диктатом сили у міжнародних відносинах;

в) глобалізація створила якісно нову ситуацію суспільної інтеграції, коли формуються міжнародні спільноти, що не мали прецедентів та висувається ідея наддержавної конституції;

г) загострення суперечностей між універсалізмом та національними особливостями, зокрема поява ціннісносистемних конфліктів у національноорієнтованих та особистісноорієнтованих суспільно-державних системах;

д) суттєвої зміни зазнають місце та роль міжнародного права у правовій системі; паралельно 3 інтернаціоналізацією права і небувалим розширенням масштабів, а також сфери впливу принципів і норм міжнародного права, відмінності традиційних правових систем стають все більш відносними;

е) одночасно значна кількість країн опинилась в зоні невизначеності, обумовленій системною перебудовою; неминучим процесом стало формування нової системи цінностей та вирішення проблем суспільного розвитку та ін.

С. В. Прилуцький (2015) підкреслює: Вже сьогодні маємо негативні наслідки безсистемного підходу, оскільки не тільки теоретики «ламають списи» у 
наукових дискусіях, а й, що найгірше механізм правосуддя та його юридична практика заганяється у глухий кут колізій вітчизняних законодавчих «новел». На цьому тлі у процесі нових реформаційних перетворень перебуває судова система, система кримінальної юстиції та правозахисту. Останні напрямки органічно включаються $\mathrm{y}$ спільні політики ЄC («сукупність нормативно-правових актів $€ C$, принципів і методів їх реалізації, які спільно впроваджуються інституціями Євросоюзу та державами-членами 3 метою досягнення визначених цілей і завдань політики») у сфері внутрішніх справ i юстиції (простір свободи, безпеки i правосуддя). Згідно Маахстрихтського договору, створення єдиної політики у цій сфері мало стати одним 3 пріоритетних i фундаментальних напрямків інтеграції європейських країн. Зміст спільної політики у сфері внутрішніх справ і юстиції полягає у формуванні сукупності правових та організаційних форм співробітництва правоохоронних і судових органів $€$, спрямованих на взаємодію в рамках спільних дій щодо притулку та імміграції, судового співробітництва і цивільних і кримінальних справах, а також поліцейського співробітництва з метою протидії транснаціональній злочинності (Dudash T. I., 2013).

Парадигма євроінтеграції включає такі елементи (Kovalenko Ye. O., 2008):

- формування знань про природу та сутність європейської інтеграції, специфіку функціонування $\epsilon C$;

- подолання психологічного пострадянського бар'єру суспільної думки стосовно нової системи Європейських координат й інтеграційних перспектив;

- створення проєвропейської більшості в суспільстві;
- забезпечення необхідних знань та навичок щодо розуміння цілей інтеграції i $\in C$ державними службовцями;

- всебічна підтримка політики уряду українським суспільством;

- набуття знань про ЄС та виховання молодих людей у дусі спільних європейських цінностей та ідеалів;

- всебічне інформування широкого кола громадськості з питань інтеграції.

Вільчик Т. Б. (2015) наголошує, що однією 3 умов інтеграції України до Європейського Союзу $є$ побудова такої системи адвокатури та створення законодавства щодо іiї організації i діяльності, норми якого відтворювали б модель демократичного правового інституту адвокатури, оскільки лише за умови належного функціонування цього інституту можливий розвиток демократії та верховенства права, що, у свою чергу, $\epsilon$ одним із головних критеріїв набуття Україною членства у Європейському Союзі. Євроінтеграційні прагнення України потребують узгодження системи правових норм України та $Є C$, зокрема, в сфері прав людини. Сталовєров В.М. (2017) акцентує на тому, що ратифікація угоди про асоціацію з Європейським Союзом засвідчила вибір Україною європейської системи цінностей та стандартів захисту прав людини, додержання яких на практиці можливе за умови реалізації принципу верховенства права, забезпечення кожному права на справедливий судовий розгляд незалежним та неупередженим судом, а також ефективного виконання своїх функцій суміжними правовими інститутами і перш за все адвокатурою України. Однією з умов досягнення членства в Європейському Союзі $\epsilon$ побудова такої системи адвокатури, яка відповідала б новим суспільнополітичним i економічним реаліям, 
розроблення законодавства, норми якого відтворювали б модель європейського інституту адвокатури.

$€$. Шкребець (2016) відзначає, що сучасне адміністративно-правове забезпечення адвокатури розвивається в складних політичних, економічних та навіть культурних умовах. Так, уся правова система перебуває під пильною увагою громадськості, міжнародних спостерігачів та взагалі всієї світової спільноти. Повноцінне входження України до Європейського Союзу потребує імплементації європейського законодавства до вітчизняного правового поля, а дотримання прав i свобод людини i громадянина $\epsilon$ невід'ємною частиною цього процесу. На цьому полі адвокатура повинна стати прикладом для всього суспільства. Роль адвокатури повинна бути посилена обов'язковою участю адвокатів в ухваленні та узгодженні законопроектів, які стосуються захисту прав громадян.

У Стратегії розвитку Національної асоціації адвокатів України (2015) визначено 4 Стратегічні цілі: зробити НААУ сильною, згуртованою та авторитетною організацією в Україні та світі; забезпечити активну участь їі членів у конституційному процесі та втіленні конституційних змін у чинне законодавство;

удосконалити процедури професійної підготовки та розвитку адвокатів; покращити ефективність системи комунікацій 3 усіма суб'єктами та учасниками правової реформи в Україні.

Зазначені цілі деталізовано у вигляді низки задач, серед яких удосконалити роботу системи органів адвокатського самоврядування в Україні та сприяти більш активному залученню адвокатів до їх роботи на національному та регіональному рівнях; підвищити вимоги щодо здійснення адвокатської діяльності, зокрема посилити професійні та моральноетичні вимоги до осіб, які мають намір отримати статус адвоката, та до дисциплінарного контролю професії; спростити процедуру доступу громадян до безоплатної правової допомоги; удосконалити систему правового регулювання професійних прав та обов'язків адвокатів, забезпечити гарантії здійснення адвокатської діяльності. запровадити ефективні механізми притягнення до відповідальності посадових осіб за порушення гарантій незалежності адвокатів; якісно змінити систему професійного розвитку та удосконалити процедуру підвищення кваліфікації адвокатів; активно розвивати співпрацю 3 міжнародними професійними організаціями адвокатів для запозичення та запровадження їх передового досвіду; удосконалити систему оподаткування адвокатської діяльності (Stratehiia rozvytku Natsionalnoi asotsiatsii advokativ Ukrainy, 2015).

Актуалізація $\quad$ євроінтеграційної парадигми у вимірі юриспруденції зумовила утворення нової доктрини інтеграційного права. У його основі розуміння інтеграції як динамічного руху до об'єднання розрізнених елементів у нову, більшу і досконалішу цілісну систему, що відзначається наявністю на сучасному етапі трьох базових компонентів: ï прагнення до вдосконалення, постійну мінливість цього динамічного процесу i його спрямованість на створення завершеної, цілісної системи (Kashkin S. Yu., 2012).

\section{вИСНовкИ}

Отже, підсумовуючи проведене дослідження, відзначимо наступне. Євроінтеграційна парадигма визначає динаміку правової реформи в Україні на найближчі роки. Євроінтеграційні прагнення обумовлюють необхідність суттєвих перетворень у різних сферах права, у тому числі й стосовно організаційно-правового забезпечення 
діяльності і розвитку адвокатури України.

Надалі доцільним $€$ дослідження концептуальних передумов досягнення незалежності адвокатури в умовах євроінтеграції України.

\section{References}

Abashydze A. Kh. (2004). Novye tendentsyy $\mathrm{v}$ normotvorcheskoi deiatelnosty $00 \mathrm{~N} v$ oblasty zashchytы prav cheloveka. Hlobalyzatsyia, hosudarstvo, pravo. $21-26$.

Arutiunian H.H. (2004). Pravovaia hlobalyzatsyia y nekotorye tendentsyy razvytyia konstytutsyonalyzma. Hlobalyzatsyia, hosudarstvo, pravo. 27 - 33.

Blyshchenko V. Y. (2004). Hlobalyzatsyia y mezhdunarodnoe pravo. Hlobalyzatsyia, hosudarstvo, pravo. 17 - 20.

Dudash T. I. (2013). Praktyka Yevropeiskoho sudu $z$ prav liudyny. K. Alerta, $368 \mathrm{~s}$.

Kashkin S. Yu. (2012). Intehratsiine pravo yak kontsentrovane vyrazhennia porivnialnoho prava: poniattia, tendentsii ta etapy rozvytku. Porivnialne pravoznavstvo, 3-4. 306-315.

Kovalenko Ye. O. (2008). Kontseptualno-metodolohichni zasady analizu yevrointehratsiinoi polityky. Humanitarnyi visnyk Zaporizkoi derzhavnoi inzhenernoi akademii, 32. 210-219.

Prylutskyi S. V. (2015). Sudove pravo yak kontseptualna osnova sudovoi vlady Ukrainy. Pravo Ukrainy, 3. 26 - 41.

Shkrebets Ye. (2016). Shliakhy vdoskonalennia administratyvnoho zakonodavstva shchodo zabezpechennia diialnosti advokatury v Ukraini. Pidpryiemnytstvo, hospodarstvo i pravo, 2. 122-127

Stalovierov V.M. (2017). Problemy reformuvannia zakonodavstva pro advokaturu ta advokatsku. Molodyi vchenyi, 5.1 (45.1). 127-132.

Stratehiia rozvytku Natsionalnoi asotsiatsii advokativ Ukrainy (2015). URL: http://unba.org.ua/assets/uploads/files/st rategiya-rozvitku-naau-do-2020-roku.pdf

Tykhomyrov Yu. A. (2004). Ynternatsyonalyzatsyia natsyonalnoho prava. Hlobalyzatsyia, hosudarstvo, pravo. $167-174$.

Vilchyk T. B. (2015). Instytut advokatury Ukrainy: novi pidkhody ta tendentsii rozvytku. Naukovyi visnyk Mizhnarodnoho humanitarnoho universytetu. Seriia: Yurysprudentsiia, 16(1). $25-28$ 